\title{
Forced Migration in Modern Europe and Russia: Situation, Problems and Possible Ways to Optimize the Refugee Law
}

\author{
Vladimir A. Volokh* \\ State University of Management \\ 99 Riazanskii Prospect, Moscow, 109542, Russia
}

Received 02.12.2015, received in revised form 18.01.2016, accepted 21.03.2016

The article by Professor V.A. Volokh is dedicated to one of the most controversial issues of our timemigration issues in and out of Russia. In the context of economic and political globalization not only basic characteristics of the international migration process have changed, but also their determinants. The EU Member States are seriously concerned about the issues of uncontrolled flow of migrants from the Middle East and try to find ways to resolve the immigration crisis. In Russia, with the increasing flow of refugees from Eastern Ukraine and other categories of migrants, this problem has also acquired great importance.

Prof. V.A. Volokh examines in detail the state migration policy of the Russian Federation, processes and mechanisms of management of migration flows, measures taken to prevent illegal immigration in the country, and suggests possible ways to optimize legislation on refugees.

Keywords: migration, forced migration, refugees, temporary shelter, the 1951 UN Convention relating to the Status of Refugees, EU countries, illegal migration flows, threats to national security, Federal Law "On Refugees", Ukrainian citizens.

DOI: 10.17516/1997-1370-2016-9-4-775-782.

Research area: politology.

In the context of economic and political globalization not only basic characteristics of the international migration have changed, but also the factors that determine them. The scale of the world's migration processes has a tendency to a permanent increase - more and more people get involved in them.

It should be noted that in the modern world there is a steady increase in legal and illegal migration flows to European countries, especially from countries with unstable socio- economic environment. According to the latest UN statistics, in 2013 the number of migrants in the world reached 232 million people, which is 57 million people more than in 2000. The top ten countries receiving the greatest number of migrants list 5 European countries, including the Russian Federation ( $2^{\text {nd }}$ place $)$, Germany ( $3^{\text {rd }}$ place), France $\left(7^{\text {th }} \text { place }\right)^{1}$.

At the same time, in countries receiving migrants there are regular protests of migrants and the indigenous population. The most advanced

(C) Siberian Federal University. All rights reserved

* Corresponding author E-mail address: v.volokh@yandex.ru 
theories and practices of regulation of migration processes, cultural and linguistic integration of migrants do not fully cope with emerging threats to national unity of European countries.

Against the backdrop of the armed conflict in the Middle East displaced people rushed to Europe, many of whom tend to get in the Western countries. As of 2015, more than 800 thousand people applied for a refugee status in European countries, according to the Times citing the UN data. Most of those wishing to apply for the refugee status in the most developed EU countries are citizens of Syria, Afghanistan and Iraq. A significant number of applications also come from labour migrants.

The Member States of the European Union are seriously concerned about the problems of an uncontrolled flow of migrants from the Middle East rushing to Europe and try to find ways to solve the immigration crisis.

Obviously, the revaluation of the applied theories and practices should begin with a discussion and development of an understanding of the object, to which they are directed - a phenomenon of "external migration". In the $20^{\text {th }}$ century, external migration was successfully managed by the recipient states. Migration was an element of foreign and domestic policy of states and to a lesser extent depended on external factors.

Modern means of communication such as the Internet, television and telephone were not readily available to migrants. Transport infrastructure was not as accessible as it is today. Thus, moving to another country of residence meant the actual loss of cultural and linguistic ties with their former homeland. The decision to migrate was a kind of an existential choice for a person.

At present, taking into account the processes of globalization, the question arises of whether globalization is an additional factor stimulating external migration or external migration is subject to a greater degree of influence of other external factors. For example, how is the tool of social, cultural and economic policies of other countries used? Modern migrants "storm" public institutions, come to "conquer" countries within the framework of cultural, religious and political movements. Migrants are actively intruding into all areas of the state activities trying to influence redistribution of financial resources of the host countries.

There is "creeping" settling of migrants in the recipient states from the border areas with the creation of enclaves across the country. External migration can also be used as a means of lobbying interests of different transnational, international organizations, communities, transnational criminal groups.

It is possible to artificially stimulate migration flows in order to destabilize the situation in the host country. The work on redistribution of the world's economic resources can also be carried out under the guise of ideological slogans and with the assistance of migrant communities.

Another most important stage of adaptation and integration of immigrants into society is granting citizenship to foreign citizens, since, in future, "new" citizens will enjoy the same rights as the native population. The desired result of naturalization is solution of demographic problems, augmentation of the cultural heritage and the economic well-being. In practice, a balance of interests of the indigenous and "new" citizens is not always struck. Newly arrived citizens in a number of cases begin to "impose" their traditions, stereotypes, culture on the indigenous population through the institute of state and law, and demand more attention from the government agencies.

As a result of the unconsidered process of naturalization the rights of the native population may be infringed. The question arises on whose rights are of greatest importance for the state - the 
rights of native citizens or the rights of migrants the future citizens of the state who arrived from foreign countries?

In deciding whether to grant citizenship to migrants, a question of how migrants perceive the host country should be considered - whether it is a resource for self-realization in their second home or an opportunity to live in a new place "by their own laws" without taking into account the views of local people.

The famous scientists Samuel Huntington ${ }^{2}$ and P.J. Buchanan ${ }^{3}$ considered such events in the field of external migration in the framework of the theory of the "clash of civilizations" that, despite its popularity, in our opinion, greatly distorts the meaning of processes that are actually taking place today. Thus, a wave of refugees from Iraq, Syria, Libya and Afghanistan was not due to a clash of civilizations, but due to the military and political operations carried out in these countries. Supporters of this theory also could not attribute the riots in France taken place in NovemberDecember 2005 to the manipulations of radical Islamic groups.

As for modern Russia, forced migration has become an issue that has not received full understanding and deliberate government decisions. Failure of the state to provide help for displaced people in a number of cases may lead to non-compliance with international obligations and reduction of the international prestige of the country and the lack of proper regulation of the legal status of foreign citizens and stateless people may increase the risk of criminal and administrative offenses.

The problem of refugees in Russia, which was almost unfamiliar in the Soviet period, has become the focus of attention of practitioners, journalists and scientists in the 1990's. ${ }^{4}$ Then, at the beginning of this century, the interest in it has significantly weakened. However, in recent years, with the growth of the flow of refugees from
Eastern Ukraine and other asylum seekers, this problem acquired great importance again.

In early 2014, as a result of the largescale use of military forces in the Donetsk and Lugansk regions, as well as the deterioration of the political and economic situation in Ukraine and pessimistic expectations of the population with respect to its development has resulted in a dramatic increase of forced immigration of Ukrainian citizens in the Russian Federation.

Based on the principles of humanism and brotherhood with the people of Ukraine Russia has consistently pursued a policy of "wide-open doors", in spite of the serious burden of their reception.

The Ukrainian citizens coming to Russia were given the opportunity to regularize their legal status in accordance with the Federal Law "On the Legal Status of Foreign Citizens in the Russian Federation" or apply for asylum in accordance with the Federal Law “On Refugees".

Today in Russia there are about 2.6 million Ukrainian citizens ${ }^{5}$. Citizens of Ukraine actively apply to the Russian Federal Migration Service units to determine their legal status. Thus, as of late October 2015 in Russia, there are more than 325 thousand people with a temporary residence permit, more than 111 thousand people - with a permanent residence permit, 149 thousand permits for employment have been issued (144 thousand patents; 5 thousand work permits). More than 311 thousand Ukrainian citizens with a refugee status or a temporary residence permit are registered.

In addition, in the period from 2014 till September 1, 2015, more than 114 thousand people arrived from Ukraine became the participants of the State Programme to Assist Voluntary Resettlement of Compatriots Living Abroad to the Russian Federation.

Thus, the Russian Federation has helped more than one million citizens of Ukraine through 
the provision of various types of international protection.

Afghanistan has also been a problematic region for a long time. This year 5.7 thousand people came from Afghanistan, which is almost $15 \%$ more than last year. More than 8.7 thousand people reside in Russia, including 4.3 thousand people with a temporary residence permit and a permanent residence permit. About 1 thousand people have a refugee status or a temporary shelter.

This year, more than 9.2 thousand citizens of Syria came to the Russian Federation, which is almost 3\% more than last year. And today there are about 7 thousand Syrian citizens living in Russia, including about 4.5 thousand people with a temporary residence permit and a permanent residence permit. More than 1.5 thousand people have a refugee status or a temporary shelter.

In general, it can be noted that the situation with citizens of Syria, Afghanistan and Ukraine arriving in the territory of the Russian Federation is within the legal framework and is fully controlled.

At the same time, the national asylum system, on the one hand, should provide socioeconomic, legal, cultural and psychological support to refugees and persons who have been granted temporary asylum, and on the other hand, the preservation of national security and internal stability in the socio-economic sphere of the host region.

A comparative legal analysis of the application of the current edition of the Federal Law "On Refugees" with the law enforcement practice of asylum in Russia has revealed a number of shortcomings of the Law.

It has a number of gaps, mainly of a procedural nature, that do not allow effective considering of applications for a refugee status, some regulations are illogical and difficult to understand, which creates problems with implementation of the Law at the present moment.

First of all, it should be noted that the procedure for recognition of a refugee status is overextended. Theintermediatestages providedfor by the current legislation, such as the preliminary examination of an application, a decision to grant notification that a request for recognition of a refugee status is under consideration on the merits or the refusal to consider the application on the merits only complicate the procedure. This leads to unnecessarily longstanding processing of an application.

In this context, it seems appropriate to exclude a stage of preliminary examination of the application from the Federal Law "On Refugees" turning this procedure into a one-step type.

It is necessary to introduce the notions of "safe country" and "safe third country", "temporary protection" at the legislative level, to clarify the concept of "family member" providing for the combination of the refugee recognition procedures and the provision of temporary shelter, which will shorten the term for determining legal status of a person who applied for asylum by three months.

It is also appropriate to provide for a mechanism of redistribution of persons who have applied for asylum in the Russian Federation territory through annual establishment by the Federal Migration Service of Russia of the distribution quota for registration of applications for a refugee status or temporary asylum in the Russian Federation for the territorial bodies.

In order to ensure security for persons seeking asylum, persons recognized as refugees and persons granted temporary asylum or temporary protection in the Russian Federation we should have a ban to disclose, without the written consent, information about these people to the state bodies, other organizations and citizens of the state of their nationality or 
former habitual residence, the media, with the exception of the Office of the UN Office of the High Commissioner on Refugees, as well as the executive bodies of the Russian Federation and other organizations, statutory activities of which involve assisting these categories of citizens in the Russian Federation.

In accordance with the provision of the 1951 United Nations Convention Relating to the Status of Refugees ${ }^{7}$, it is appropriate to provide for an exception from the principle of non-refoulement of persons whose stay in the territory of the Russian Federation threatens Russian national security, or persons convicted by a final judgment of the court for the committing a particularly serious crime in the Russian Federation who pose a threat to public safety.

In our opinion, there is no need to accept applications for asylum outside the Russian Federation on the territory of third countries, since in this situation, when the applicants are not under the jurisdiction of the Russian Federation, it is impossible to provide adequate international protection and verify the validity of their applications. Also we should take into account a special procedure for considering applications for asylum of persons who are in a transit zone of an international airport or international sea or river ports of the Russian Federation. An important innovation in the law should be the establishment of clear criteria for granting temporary asylum to foreign citizens in the Russian Federation.

Probably, it is necessary to exclude the pretrial appeal in the Federal Migration Service of Russia of the territorial bodies' decisions, and to clarify the procedure for considering claims in courts. Such measures will reduce the deadlines for claims against decisions of the territorial bodies of the FMS of Russia to 15 days, and in some cases up to seven days from the day of familiarization with the decision by a person.

We also should particularly note the need to arrange the order of reception of migrant populations in the event of the emergency, mass arrival in the Russian Federation in search of temporary protection by determining the legal status of persons who were granted temporary protection.

Thus, in the provision of international protection to asylum seekers in the Russian Federation, there are still gaps that, in the author's opinion, should be solved by making appropriate amendments and changes in the existing legal framework.

Another aspect is the security problem. In recent years, there is a growing number of terrorist acts committed in countries receiving immigrants by naturalized foreigners on ideological and radical religious grounds. In this regard, there is a need to develop new approaches to control processes of population migration at different levels of government regulation in the areas of cultural, educational, social, economic, foreign and domestic policies that will contribute to the development of effective measures for the timely response to the challenges and threats to national security.

\footnotetext{
UN press-release // http://www.un.org/ru/ga/68/meetings/migration/pdf/internationalmigrantsworldwide_totals2013.pdf Huntington, S. The Clash of Civilizations. Moscow, 2003

Buchanan, P.J. Death of the West. Moscow, 2003

4 Volokh, V.A. The formation and implementation of the state migration policy of the Russian Federation in the field of forced migration and asylum system. Monograph. M.: Publishing house "Sputnik +", 2009.

5 In the temporary accommodation centers (there are 299 such centers in the Russian Federation) there are about 16.4 thousand people, including 5.2 thousand children. 567 thousand people are accommodated in inner suburbs.

6 Federal Law of 19 February 1993 No. 4528-I "On Refugees" (as amended) GARANT system: http://base.garant. $\mathrm{ru} / 10105682 / \#$ ixzz3s2tqHKaI

The 1951 United Nations Convention (Geneva, July 28, 1951) GARANT system: http://base.garant. ru/2540374/\#ixzz3s2ujyVOf
} 


\section{References}

Voronina, N.A. (2010). Migratsionnoe zakonodatel'stvo Rossii: sostoianie, problem, perspektivy [Migration Legislation in Russia: situation, problems and prospects]. Moscow, Publishing house "Sputnik +".

Voronina, N.A. (2002). Obespechenie prav cheloveka v oblasti migratsii: mezhdunarodnye i natsional'nye standarty i mekhanizmy [Ensuring human rights in the field of migration: international and national standards and mechanisms]. In Prava cheloveka: itogi veka, tendentsii, perspektivy [Human Rights: results of the century, trends and prospects]. Ed. Lukasheva, E.A. Moscow: Norma.

Voronina, N.A. (2003). The activities of public organizations in Russia to protect the rights of migrants in Russia [Deiatel'nost' obshchestvennykh organizatsii Rossii po zashchite prav migrantov v Rossii]. Prava cheloveka i pravozashchitnaia deiatel'nost' gosudarstva [Human Rights and the human rights activities of the state]. Collected materials of All-Russian scientific-practical conference, May 12, 2003. Ed. Doctor of Law Lopatin, V.N. Saint-Petersburg, Publishing house "Iuridicheskii tsentr Press".

Voronina, N.A., Volokh, V.A., Volodin, E.V. (2014). Administrativno-pravovye protsedury $i$ rezhimy $v$ sisteme migratsionnykh pravootnoshenii $v$ otnoshenii inostrannykh grazhdan $i$ lits bez grazhdanstva [Administrative and legal procedures and modes in a system of legal migration relations of foreign citizens and stateless persons]. Moscow: GUU, 139 p.

Volokh, V.A. (2015). Novaia Rossiia: politika i upravlenie migratsionnymi protsessami [New Russia: policy and management of migration processes]. Samara, Publishing House "Bakhran-M", $192 \mathrm{p}$.

Volokh, V.A. (2009). Formirovanie i realizatsiia gosudarstvennoi migratsionnoi politiki Rossiiskoi Federatsii $v$ sfere vynuzhdennoi migratsii i predostavleniia ubezhishcha [The formation and implementation of state migration policy of the Russian Federation in the field of forced migration and asylum]. Moscow, Publishing house "Sputnik +".

Volokh, V.A., Volodin, E.V. (2015). Predostavlenie ubezhishcha v Rossiiskoi Federatsii inostrannym grazhdanam i litsam bez grazhdanstva: protsedura rassmotreniia khodataistva i poriadok ikh trudoustroistva. [Asylum for foreign citizens and persons without citizenship in the Russian Federation: the application procedure and the procedure of their employment], in Vestnik universiteta GUU [Bulletin of the University (SUM)], 2015.

Volokh, V.A., Volodin, E.V.(2015). Poriadok trudoustroistva inostrannykh grazhdan, poluchivshikh status bezhentsa ili vremennoe ubezhishche v Rossiiskoi Federatsii [The procedure for employment of foreign citizens granted a refugee status or temporary asylum in the Russian Federation], in Voprosy prava i politiki [Law and Policy Issues].

Kontseptsiia gosudarstvennoi migratsionnoi polotiki Rossiiskoi Federatsii na period do 2025 goda [The concept of the state migration policy of the Russian Federation for the period up to 2025]. Approved by the President of the Russian Federation on June 13, 2012.

Krylov, K.D. (2015). New political and legal initiatives in the promotion of social justice for the fair globalization [Novye politico-pravovye initsiativy v prodvizhenii sotsial'noi spravedlivosti $\mathrm{v}$ tseliakh spravedlivoi globalizatsii]. "Sotsial'naia spravedlivost' $i$ gumanizm $v$ sovremennom gosudarstve i prave" ["Social justice and humanism in the modern state and law"]. Ed. Soshnikova, 
T.A., Materials of the international conference. Moscow, Publishing house Moskovskii Gumanitarnyi Universitet, 43-46.

Krylov, K.D. (2009). Priorities and legal guidelines for further legislation in the field of migration [Prioritety i pravovye orientiry dal'neishego zakonotvorchestva v oblasti migratsii]. Parlamentskie slushaniia [Parliamentary hearings]. Improvement of legislation in the field of attraction and use of foreign work force in the Russian Federation. May 21, 2009. Moscow: Federal'noe Sobranie Rossiiskoi Federatsii. Sovet Federatsii, 36-38.

Roshchin, Iu.V. (2012). Migratsiia v sud'be Rossii [Migration in the fate of Russia]. Moscow-Tver, Publishing House "Avangard": Sed'maia bukva.

Soshnikova, T.A. (2014). Puti povysheniia roli professional'nykh soiuzov v sovremennoi Rossii [Ways of enhancing the role of trade unions in modern Russia]. Moscow, Publishing house Moskovskii Gumanitarnyi Universitet, 152 p.

Suvorova, V.A. (2011). Opyt Rossii v oblasti protivodeistviia torgovle liud'mi [Russia's experience in the field of combating human trafficking], In Vestnik universiteta [Bulletin of the University]. 11, Moscow, GUU.

Suleimanova, Sh.S. (2009). Natsional'naia politika Rossii i SMI (1990-2000): teoriia i praktika [National policy of Russia and the mass media (1990-2000): Theory and Practice]. Moscow, Publishing house RAGS. 


\section{Вынужденная миграция \\ в современной Европе и России: \\ состояние, проблемы, \\ возможные пути оптимизации \\ законодательства о беженцах}

\section{В.А. Волох \\ Государственныци университет управления России Россия, 109542, Москва, Рязанский проспект, 99}

Статья профессора В.А. Волоха посвящена одной из самых острых тем современности проблемам миграџии вокруг и внутри России. В условиях экономической и политической глобализации претерпели изменения не только базовые характеристики международных миграчионных прочессов, но и определяющче их факторы. Страны - члень ЕС серьезно обеспокоень вопросами неконтролируемого потока мигрантов с Ближнего Востока и пыттаются найти пути урегулирования миграционного кризиса. В России по мере нарастания потока беженцев с востока Украины и других категорий мигрантов эта проблема также приобрела серьезное значение.

Профессор В.А. Волох подробно рассматривает государственную миграционную политику Российской Федерации, процессы и механизмы управления миграционными потоками, принимаемые меры по недопущению незаконной миграции на территорию страны, а также предлагает возможные пути оптимизации законодательства о беженцах.

Ключевые слова: миграция, вынужденная миграция, беженцыь, временное убежище, Конвенция ООН 1951 года о статусе беженцев, страны Евросоюза, нелегальные миграционные потоки, угрозы нацииональной безопасности, Федеральный закон РФ «О беженцах», граждане Украиньл.

Научная специиальность: 23.00.00-политология. 